\title{
Protein Sprouty Homolog 2
}

National Cancer Institute

\section{Source}

National Cancer Institute. Protein Sprouty Homolog 2. NCI Thesaurus. Code C106029.

Protein sprouty homolog 2 (315 aa, $\sim 35 \mathrm{kDa}$ ) is encoded by the human SPRY2 gene. This protein is involved in antagonism of growth factor signaling pathways. 